International Journal of Social Science and Economic Research

ISSN: 2455-8834

Volume:06, Issue:07 "July 2021"

\title{
AN OVERVIEW OF RETURN MIGRATION DURING LOCKDOWN
}

\author{
Dr.Madhu G $\mathrm{R}^{1}$ and Prof. Uma H. $\mathrm{R}^{2}$ \\ ${ }^{1}$ DOS in Economics and Cooperation, University of Mysore, Manasagangothri, Mysuru -05 \\ ${ }^{2}$ Professor of Economics, Sir.M.V.P G centre, University of Mysore, Thubinakere, Mandya \\ DOI: 10.46609/IJSSER.2021.v06i07.037 URL: https://doi.org/10.46609/IJSSER.2021.v06i07.037
}

\begin{abstract}
The present study tries to analyse the migration trends during lockdown based on the available data from the census of India 2001 and 2011 and critically analysed the current policies to address the new emerging to make provision of immediate relief to migrants, employment generation in native places to sustain to returnees and incentivize the city makers to return to host places. The paper found that union and state governments are announcing many programme and schemes to address the unexpected uncertainties created by the COVID-19 pandemic. The union government announced the direct cashtransfer, enhanced funds to MGNREGS for additional employment, Pradhan Mantri Garib Kalyan Yojana (PMGKY), andFree Food Distribution, Employment Creation, and social security schemes to reduce the vulnerability of return migrants and informal sector labourers. Lastly, the author tries to examine the sufficiency and feasibility of public policies in this pandemic situation.
\end{abstract}

Keyword: Corona, COVID-19, Pandemic, Outbreak, vulnerable

\section{Introduction}

The announcement of the county-wide lockdown in India to arrest the spread ofthe COVID-19 pandemic in March 2020 has been appropriate, lauded as an effective pre-emptive strategy. However, it has also been instrumental in the unintentional creation of multi-layered problems for the economy ranging from production on one hand and demand, or income, on the other hand,one of the big challenges is the mass return of the migrants from destination centers to home to escape the starvation and dwindled access to essential items, brought on by the sudden loss of employment and lack of effective social protection mechanism. According to the 2011 census, the internal migration rate was $44.9 \%$ between 2001-11; the internal growth rate exceeded the population growth rate of $18 \%$ during the same period. The total number of internal migrants stood at a staggering 455.7 million in 2011(Dandekar \&Ghai, 2020). The major push for high internal migration in India is a regional disparity, unemployment, lack of job 
International Journal of Social Science and Economic Research

ISSN: 2455-8834

Volume:06, Issue:07 "July 2021"

opportunity, poverty, lack of skill and skill mismatch, etc. At the same time, the host destinations provide them employment opportunities. A disproportionate share of these labourersresides and works in dismal conditions as informal workers and has none or a very smallsavings amount. These small saving meant they did not have a buffer to deal with the unexpected share turn uncertainties of the Corona pandemic.

The luck of urban centers is the worst and is also in primary destination centers for workers from other places. According to the Center for Monitoring the Indian Economic (CMIE), the urban unemployment rate strictly increased from $9.41 \%$ to $24.95 \%$ between March and April 2020 before picking on May 20th, 20 to $25.79 \%$. The major sectors affected by the countrywide lockdown included construction, hotels, manufacturing, trade, and restaurants that collectively account for $55.2 \%$ of the total urban employment (PLFS Report, 2019-20). According to the Ministry of Commerce estimation, the growth rate of the index of 8 core industries (which constitute roughly $40 \%$ of the IIP) for June 2020 declined by $15.0 \%$ (provisional) compared to a decline of $22.0 \%$ (revised) in the previous month of May 2020. Its cumulative growth from April to June 2020-21 was -24.6\%. Except for fertilizer, all industries suffered a huge decline. These sectors are the major employment generating sectors, resulting in worsening conditions for this group's destination centers. As per the World Bank study, roughly 40 million internal migrants were affected by the lockdown.( Ratha et al.,2020). The informal workers' nationwide survey revealed that more than $81 \%$ of the informal sector workers lost their livelihood. In comparison, the figure was relatively lower for non-migrant labourers (71\%). 35\% who are participated in the survey said they had received full wages during the lockdown, while $48 \%$ declare they have not received wages.

The lift of bans on inter-district and interstate return migration brought to the forefront of policy discussion not only immediate issues of their vulnerability, but it also creates issues pertaining to pertaining to the identification, informal and dismal employment conditions in destination centers, including lack of low bargaining power and, social security. Migrant workers, especially inter-state migrants, are affected due to the non-portability of entitlement and identification issues.

Due to the unexpected uncertainties, the government has encountered primary challenges regarding migrants. The first challenge is to arrange the basic needs, social protection, and health facilities for unskilled and semi-skilled labourers. Second, creating jobs for the return migrants at native places. Further, incentivizing the 'city makers' to stay/ for return migrants to return to the destination centers. These are especially important because migrant labourers contribute to the host areas through their labour and skill and invest and pay indirect taxes to the economy. 
International Journal of Social Science and Economic Research

ISSN: 2455-8834

Volume:06, Issue:07 "July 2021"

The Finance Minister has announced a 20 lakh crores stimulus package to tackle the pandemic situation. This paper analyzes the return migration trends based on available data from the 2001 and 2011 censuses. The present study focuses on an inter-state flow of migration and examines the government's responses to address return migration challenges.

\section{An overview of Inter-State Migration in India}

The NSSO and census are the major data source of the migration studies in India. There are no other sources and accurate time-series data available in India. Even available census and NSSO data also suffer from inherent severe methodological issues. NSSO conducted the migration survey in 2007-08 and the last census data available for 2011. These nine to ten-year data are outdated and may not represent the present migration trends in the country. Many researchers proved that these figures are underestimated the total internal migration. This can be accrued that neither census nor NSSO accurately captures the seasonal or circular flows, which are largely part of overall migration processes (Dandekar \&Ghai, 2020; Deshingkar\&Akter, 2009). Infact, Deshingkar\&Akter (2009) have estimated that in 2008 Indian internal migration was 100 million. A large number of migrant labourers are excluded from the migrant status due to the rigid definition of migration and lack of enumeration, especially seasonal migrants. Of the informal workforce in urban India, 100 million people, or 1 in 10 Indians, are seasonal/circular/short-term migrants (Thomas et al., 2020). Given the limitations in the migration data availability, the census is considered the most reliable and latest data.

According to the 2011 census, internal migration in India was 449.9 million in $2011,37.2 \%$ of the total population and $98.7 \%$ of the country's total migrants. Total internal migration has increased at a rate of $3.82 \%$ per annual between 2001-2011. During the same period, the population growth rate in India was $1.64 \%$ per annum. It indicates a significant increase in the labour movement within the country.

Total Migrants in India by Last Residence, 2001-2011

\begin{tabular}{|l|l|l|l|l|l|l|}
\hline & $\begin{array}{l}2011 \\
\text { (in } \\
\text { Millions) }\end{array}$ & $\begin{array}{l}\text { Share of } \\
\text { Total } \\
\text { migrants } \\
(\%)\end{array}$ & 2001 & $\begin{array}{l}\text { Share } \\
\text { oftotal } \\
\text { (inMillions) } \\
(\%)\end{array}$ & $\begin{array}{l}\text { Rate ofgrowth } \\
\text { Between2001- } \\
2011(\%)\end{array}$ & $\begin{array}{l}\text { Rate } \\
\text { growth } \\
\text { Between2001- } \\
2011(\%)\end{array}$ \\
\hline Intra-State & 395.7 & 86.8 & 268.2 & 85.3 & 47.5 & 3.96 \\
\hline Inter - state & 54.3 & 11.9 & 41.2 & 13.1 & 31.8 & 2.80 \\
\hline
\end{tabular}


International Journal of Social Science and Economic Research

ISSN: 2455-8834

Volume:06, Issue:07 "July 2021"

\begin{tabular}{|l|l|l|l|l|l|l|}
\hline $\begin{array}{l}\text { Fromother } \\
\text { countries }\end{array}$ & 5.9 & 1.3 & 5.1 & 1.6 & 13.8 & 1.31 \\
\hline $\begin{array}{l}\text { Total } \\
\text { migrants }\end{array}$ & 455.8 & 100 & 314.5 & 100 & 44.9 & 3.78 \\
\hline $\begin{array}{l}\text { Total } \\
\text { internal } \\
\text { migrants }\end{array}$ & 449.9 & 98.7 & 309.4 & 98.4 & 45.4 & 3.82 \\
\hline $\begin{array}{l}\text { Total } \\
\text { population }\end{array}$ & 1210.9 & - & 1028.6 & - & 17.7 & 1.64 \\
\hline
\end{tabular}

Source: https://censusindia.gov.in/Census_And_You/migrations.aspx

The data revealed that intrastate migration accounts for the lion's share of internal migration in India in both the 2001 and 2011 censuses comprising $85 \%$ and $86.8 \%$ of the total migration, respectively. At the same time, interstate migration is a small share of the total migration from $13.1 \%$ to $11.9 \%$ from 2001-11. Because farm and non-farm labourers are migrating to the small distances orneighbor districts for searching employment. The total interstate migration population is still significant in an absolute sense. It increases from 41.2 million to 54.3 million with an average growth rate of 2.8\% per annum during 2001-11.

Table 2: Stream of Migration for internal migrants in 2011

\begin{tabular}{|l|l|l|l|l|}
\hline Stream of migration & \multicolumn{2}{|l|}{ Interstate } & \multicolumn{2}{l|}{ Intrastate } \\
\hline Rural-Rural & $1,20,19,426$ & $22.2 \%$ & $20,17,39,806$ & $51.0 \%$ \\
\hline Urban-Rural & $28,89,303$ & $5.3 \%$ & $2,40,85,918$ & $6.1 \%$ \\
\hline Urban-Urban & $1,68,07,989$ & $31 \%$ & $6,12,92,128$ & $15.5 \%$ \\
\hline Rural-Urban & $1,96,16,060$ & $36.1 \%$ & $5,85,85,417$ & $14.8 \%$ \\
\hline Unclassifiable to rural & $9,86,521$ & $1.8 \%$ & 33695236 & $8.5 \%$ \\
\hline Unclassifiable tourban & $19,45,450$ & $3.6 \%$ & 16254164 & $4.1 \%$ \\
\hline Total & & & & $100.0 \%$ \\
\hline
\end{tabular}

Source: Census of India, 2011 
International Journal of Social Science and Economic Research

ISSN: 2455-8834

Volume:06, Issue:07 "July 2021"

Table-2 presents the four migration streams, according to the 2011 census. The highest $(51 \%)$ migration accounted for rural- rural migration, where rural-urban migration is $14.8 \%$. On the other hand, across state migration, the principal channel has been rural to urban $(36.1 \%)$. Interstate migration was only 12 million out of 54.3 million belongs to rural migration flows. $31 \%$ of the migrants are moving from urban - urban. The migration to the urban constituted $70.7 \%$ of the total interstate migration, while $34.4 \%$ are intrastate migrants. The migration shows revealed that interstate migration has urban-centric and intrastate migration has rural centric.

States as per Net In-migration (any duration of residence), Census 2011

\begin{tabular}{|l|l|l|l|}
\hline States & $\begin{array}{l}\text { Net In-migrants } \\
\text { from other states } \\
\text { (in a million) }\end{array}$ & $\begin{array}{l}\text { Total Immigrants } \\
\text { from other states }\end{array}$ & $\begin{array}{l}\text { \% share of 2011 } \\
\text { population }\end{array}$ \\
\hline Maharashtra & 6 & 9.1 & $8.1 \%$ \\
\hline NCT of Delhi & 4.8 & 6.3 & $37.7 \%$ \\
\hline Gujarat & 2.3 & 3.9 & $6.5 \%$ \\
\hline Haryana & 1.3 & 3.6 & $14.3 \%$ \\
\hline Punjab & 0.7 & 2.5 & $9 \%$ \\
\hline
\end{tabular}

Source: Census of India, 2011.

The table presents the top 5 internal migration destinationsin India. The top five states as per the 2011 census for any residence were Maharashtra (6 million), NCT of Delhi (4.8 million), Gujarat (2.3 million), Haryana (1.3 million), and Punjab (0.7 million), all high GSDP states. In terms of total migration stood first with 9.1 million migrants, followed by Delhi, Haryana, and Gujarat. Delhi has the highest total migrants from other states as a proportion of its population.

In terms of migrant-sending states, Uttar Pradesh and Bihar are the major net out-migration states, which is 8.3 million and 6.3 million respectively in 2011. Rajasthan is another net emigrant state with 1.2 million net out migrants. More than 12.3 million people move to other states from Uttar Pradesh, followed by Bihar with 7.5 million and Rajasthan is with 3.8 million. 
International Journal of Social Science and Economic Research

ISSN: 2455-8834

Volume:06, Issue:07 "July 2021"

\section{Reasons for Migration by Gender, Census 2011}

\begin{tabular}{|c|c|c|c|c|c|c|}
\hline \multicolumn{7}{|c|}{ Inter-State Migrants } \\
\hline & Persons & Males & Females & Persons & Male & Females \\
\hline Work & $1,34,20,989$ & $1,19,73,661$ & $14,47,328$ & $24.7 \%$ & $50.2 \%$ & $4.8 \%$ \\
\hline Education & $7,44,015$ & $5,05,884$ & $2,38,131$ & $1.4 \%$ & $2.1 \%$ & $0.8 \%$ \\
\hline Family & $3,24,55,607$ & $71,31,606$ & $2,53,24,001$ & $59.8 \%$ & $29.9 \%$ & $83.3 \%$ \\
\hline Others & $76,44,138$ & $42,58,661$ & $33,85,477$ & $14.1 \%$ & $17.8 \%$ & $11.1 \%$ \\
\hline Total & $5,42,64,749$ & $2,38,69,812$ & $3,03,94,937$ & $100.0 \%$ & $100.0 \%$ & $100.0 \%$ \\
\hline \multicolumn{7}{|c|}{ Intra-State Migrants } \\
\hline & Persons & Males & Females & Persons & Male & Females \\
\hline Work & $3,09,29,324$ & $2,51,68,053$ & $57,61,271$ & $7.8 \%$ & $21.0 \%$ & $2.1 \%$ \\
\hline Education & $27,53,894$ & $46,58,223$ & $19,04,329$ & $1.2 \%$ & $2.3 \%$ & $0.7 \%$ \\
\hline Family & $27,51,09,194$ & $4,68,73,393$ & $22,82,35,801$ & $69.5 \%$ & $39.2 \%$ & $82.7 \%$ \\
\hline Others & $8,49,55,928$ & $4,48,02,500$ & $4,01,53,428$ & $21.5 \%$ & $37.5 \%$ & $14.5 \%$ \\
\hline Total & $39,56,52,669$ & $11,95,97,840$ & $27,60,54,829$ & $100.0 \%$ & $100.0 \%$ & $100.0 \%$ \\
\hline
\end{tabular}

The table presents the major push factors for labour migration for internal migration (inter-as well as intra-state migration). The table clearly shows that internal migration's primary reason is 'work' accounted for $24.7 \%$ of inter-state and only $7.8 \%$ for intra-state migration. Gender-wise, reasons for male internal migration was job/work/ business (50.2\%), females migrate to familyrelated reasons $(83.3 \%)$, in general,marriage $(31.1 \%)$, in particular. The pattern of inter-state migration and the reasons for the same,collectively, point to the fact that migration has been driven primarily by regional development disparities (Das \&Saha, 2013). The more developed 
International Journal of Social Science and Economic Research

ISSN: 2455-8834

Volume:06, Issue:07 "July 2021"

and urban-centric states are major destinations for internal migrants from other poor and underdeveloped states. Education, family, and other reasons are the major factors of internal migration.

Table 5: Level of Education of Inter-State Migrants who had migrated for 'Work or Employment' between 2001 and 2011(0-9 duration of residence considered)

\begin{tabular}{|l|l|l|l|l|l|l|}
\hline \multirow{2}{*}{ Level of education } & \multicolumn{3}{|c|}{ Figures } & \multicolumn{3}{c|}{$\%$ Share } \\
\cline { 2 - 7 } & Persons & Males & Females & Persons & Males & Females \\
\hline Illiterates & 1082472 & 822487 & 259985 & $18.5 \%$ & $15.9 \%$ & $38.5 \%$ \\
\hline $\begin{array}{l}\text { Literate but without } \\
\text { classifiable education } \\
\text { level }\end{array}$ & 231689 & 206467 & 25222 & $4.0 \%$ & $4.0 \%$ & $3.7 \%$ \\
\hline $\begin{array}{l}\text { Literate below } \\
\text { Secondary }\end{array}$ & 1858136 & 1720784 & 137352 & $31.8 \%$ & $33.3 \%$ & $20.3 \%$ \\
\hline $\begin{array}{l}\text { Secondary but below } \\
\text { Graduate }\end{array}$ & 1419250 & 1332619 & 86631 & $24.3 \%$ & $25.8 \%$ & $12.8 \%$ \\
\hline $\begin{array}{l}\text { Technical education } \\
\text { but Not equivalent to } \\
\text { degree }\end{array}$ & 93923 & 82656 & 11267 & $1.6 \%$ & $1.6 \%$ & $1.7 \%$ \\
\hline $\begin{array}{l}\text { Graduate and above } \\
\text { (Technical +nontechnical) }\end{array}$ & 1165500 & 1010155 & 155345 & $19.9 \%$ & $19.5 \%$ & $23.0 \%$ \\
\hline \begin{tabular}{l} 
Total \\
\hline
\end{tabular} & 5850970 & 5175168 & 675802 & $100 \%$ & $100 \%$ & $100 \%$ \\
\hline
\end{tabular}

Source: Authors' calculation from D7 Census, 2011

Note 1. 'Literate' includes figures for 'literates without educational level' and 'educational levels not classifiable.'

2. 'Matric/Secondary but below graduate' includes 'non-technical diploma or certificate not equal to a degree.'

3. This table excludes migrants; whose place of the last residence is unclassifiable as Rural or Urban. 


\section{International Journal of Social Science and Economic Research}

ISSN: $2455-8834$

Volume:06, Issue:07 "July 2021"

4. This table also excludes migrants from outside India.

The table presented the education-wise internal migrants in 2011.Roughly one-fifth of the individual migrants have degrees and above migration, implying better employment opportunities for them at the destination states. $18.5 \%$ are illiterates. They are working in the informal and unorganized sectors to meet the labour demand, for the poorly remunerated sector is expected to be quite high. The majority of urban employment is informal. According to the NCEUS, 2007 study, 93\% of the labourers work in the informal sector, which has been expected to grow. Micro studieshave shown that 'urban growth has been exclusionary and exploitative, leading tothe reproduction of poverty and socio-economic inequalities at the work destinations' (Breman, 2013; Shah and Lerche, 2018). The second major challenge was to specify that interstate migrants lack availability as state borders are crossed. The third major issue has been that interstate migrates often excluded from education, healthcare, housing, and formal institutional lending. The reasons can not only identify but also bureaucratic and linguistic hurdles. A large amount of migration to the urban center put pressure on the resources leading to a higher housing price. Other facilities will create vulnerability for migrants - the vulnerability of migrants in the pandemic reflection of the underlying systemic issues affecting this group for years.

According to the 2011 census, there are 450 million internal migrants in-country by the 'Place of Last Residence' metric, accounting for $37.7 \%$ of the total population (Registrar General of India 2011). Based on the estimation by the Gupta 2020, around 600 million internal migrants in 2020. One-third are interstate and inter-district migrants, which accounts for 200 million, and within these 200 million two thirds are estimated to be migrant labourers that roughly constitute 140 million. He found that most internal migrants in India are intradistrict short-distance migrants, it is almost $62 \%$ according to census 2011. 12\%of the migrants are long-distance interstate internal migrants, which is relatively low compared to the other developing countries like China and Brazil. Kone et al. 2018 found that a number of reasons for the trends in internal migration, most among them are the non-portability of social security benefits like subsidized public distribution system of food and the constraints on employment opportunities at the destination. According to Keshri and Bhagat 2013, many migrants are seasonal and temporary migrants, with 21 out of 1000 labourers being seasonal and temporary labourers in 2007-08. The studies bySrivastava and Sutradhar 2016; Government of India 2017b, shows that the bulk of these migrant labourers hail from marginalized and low-income quintile. The majority of the migrants are engaged in the informal sector. Some are working in the most vulnerable conditions. Most of them are excluded from social security schemes and even basic rights in the workplace. 


\section{International Journal of Social Science and Economic Research}

ISSN: $2455-8834$

Volume:06, Issue:07 "July 2021"

Women migrants are accounted for half of the migrants in India. However, male migrant labourers are migrating for the reason of work/job. Most female migrants migrate for marriage and associated purposes. (Rajan, 2013; Rajan and Sumeetha 2019a). Recent studies found that female migration has increased or feminized employment on the rise (Neetha 2004; Rajan and Neetha 2018; Mahapatro 2020; Parida and Madheswaran 2020). The economic survey 2016-17 estimated that interstate migrants are around 60 million and 80 million are inter-district migrants. The average annual flow of migrants between states was calculated at 9 million. However, this number is based on the railways, which is the country's popular transportation mode for migrants. But some of the data suffer from some the drawbacks, such as the lack of consistent, wide-ranging data on migration, which has made legislation and policy framing far more difficult. These features of internal migrants are underestimation on the part of the governments came to light with the onset of the Covid-19 pandemic.

\section{Policy Initiatives for Migrant Workers during Pandemic: An inquiry}

The government at different levels announced several policies to reduce the vulnerability of the return migrants and poor.If not alleviating the constantly deteriorating circumstances of the poor migrant labourers, particularly seasonal migrants and those working in the pandemic's informal sector. It is increasing pressure in the net out-migration states to incentivize to return to the host states. It is because it is expected that the cities with large economic activities can employ a large number of labourers immediately as the economy picks up. These urban centers also have a higher amount of GSDP and tax resources. Thereby providing them with the necessary fiscal space to generate employment and provide some social security provisions to create jobs and provide social security provisions for the migrants when they return.

Central and state announce several programmes to reduce the burden of poor, migrants, and vulnerable sections. On March 26 ${ }^{\text {th }}$, the Prime Minister announced Pradhan Mantri Garib Kalyan Packages (PMGKP) worth Rs.1.7 crore. The package aims to target the poor. The program includes a cash transfer program under PM Jan Dhan Yojana for women, Rs. 3500 crores allocated to free food for migration labourers, Rs 3000 crore for direct cash transfer to 'Widows,' 'Senior Citizens,' and 'Physically Handicapped,' PM-KISAN package for farmers worth Rs.17,500 crores. Rs. 13000 crores towards the Ujjwala Scheme (a program to distribute 50 million LPG connections to women of Below Poverty Line families), Rs 40000 crore enhanced funds to the MGNREGS, and Rs 6000, and Rs. 6000 crores towards employment for tribals/Adivasis (CAMPA), and Rs 2500 crore for Employees Provident Fund (EPF).This central government announced the free food distribution for three months under the Public Distribution System (PDS), health insurance entitlement to health workers. Around Rs. 31000 crores announced to construction workers, and Rs. 35925 for District Mineral Fund. 
International Journal of Social Science and Economic Research

ISSN: 2455-8834

Volume:06, Issue:07 "July 2021"

India's Prime Minister announced the 20 lakh crores package after 48 days of the nationwide lockdown announcement. The package includes the RBI stimulus of Rs. 20,97,053 crores under the AtmaNirbhar Bharat Abhiyan., 1.70 lakh was announced under the union budget. Rs. 3 Lakh crores collateral-free loans to micro-small and medium (MSMEs) and through Kisan Credit Card around Rs. 2 lakh crores 'concessional credit', RBI liquidity infusion for around Rs. 8 lakh crore, Infrastructure fund of Rs. 1 lakh crore from NABARD, and around Rs. 1.9 lakh crore from other liquidity measures. Many researches show that the actual funds are lower than the funds announces by the government. According to the Barclays Research calculation, the government announced cost only 1.5 lakh crores, and the SBI research group revealed it as only 2.03 lakh crores. CARE Rating as Rs. 2.8 lakh crore, Ernst \& Young as 3.08 lakh crore. Irrespective of the government's actual cost, it is true that a large portion of the announced package as a part of the liquidity decision of RBI of the 'fiscal stimulus package' and the government expenditure. This action also implies that fresh government spending will be considerably lower than the projected amount. It is clear from the studies, a small portion of the announced amount was allocated to direct cash transfer, food distribution, and immediate employment generation programme by the Union Government. Central government stress on infrastructure development projects for creating employment for migrants and other labourers.

Direct Cash Transfer: the central government announced various schemes for the vulnerable section of people, one of the major schemes was Pradhan Mantri Garib Kalyan Yojana (PMGKY). For immediate relief measure government allocated 1.70 lakh crores under the scheme. Though it is a direct cash transfer scheme, there are no schemes to address migrants and labourers who lost their jobs. While identification is difficult just after the lockdown imposed, various Panchayat and other institutions are trying to collect the data regarding migrant workers. However, the various state government also announce different programmes to their return migrants and jobless workers.

Free Food Distribution: The government distributing the three-month free food through the Public Distribution System. Migration identification and consequent difficulties for entitlement for the PDS have grave concern for the migrants as an urgent measure. The central government announced the $5 \mathrm{~kg}$ grain per person and $1 \mathrm{~kg}$ channa per family per month to all migrant who does not have either a central or state PDS card. As per the government estimation, roughly 8 crore migrants are eligible to access the benefit, and Rs. 3500 crores are allocated. Most of the state governments provide free food, shelter, and essential commodities to the migrants.

Employment Creation: one of the most challenging governments is to generate jobs forthose who lost their jobs during the lockdown, but there is no proper estimation of jobless labourers. According to the CMIE estimates on statistics on unemployment, the unemployment rate was 


\section{International Journal of Social Science and Economic Research}

ISSN: $2455-8834$

Volume:06, Issue:07 "July 2021"

8.67 percent. The highest unemployment rate of 14.11percnet was in the last week of June. Manyresearch opined that unemployment and labour distreswereas in rural areas, as the agriculture activities were seasonal, led to higher unemployment and migrant who are working in the retail and hospital sectors or will face longer unemployment. The employment generation to make up for the loss of Jobs, jobs creation through two channels - (1) direct state intervention to the job creation and (2) through indirect intervention by providing impetus to the economic activities. Through policies, intervention, the government intended to create employment for the return migrant returning to their native places, 'reverse migration' as the lockdown was lifted has been a pervasive phenomenon. Particularly those who are returning to rural areas, the rural areas do not employ the returnees. Due to the lack of diversification in agriculture, land reforms, infrastructure bottlenecks, and low productivity, employment generation are exceptionally low in rural areas. According to the PLFS estimation, the agriculture sector employed $57.8 \%$ in 2018 19. Only $13 \%$ employed in the industrial sector, $7.8 \%$ in manufacturing and other services (8.3\%). MGNREGs also unable to accommodate all labourers who lost their jobs; consequently, in pre-emptive action, the central government increased the budget for MGNREGS by Rs. 40,000 crores and above the 2020-21 budget allocation of Rs.61,500 crore. As per the Ministry of Finance estimation, it will help to generate 300 person crores days employment.

Social Security: one of the major requirements for the migrant labourers is basic social security. As an immediate measure government announces the 'One nation, One ration card.' Under this ration, cards are portable to allow return migrants to access PDS from fair price shops. Under the initiative, 67 crore beneficiaries in 23 states covering $83 \%$ of the BPL families. Further, liveable accommodations, minimum health securities, decent work hours, and proper nutrition are other government intervention priorities. Pradhan Mantri Awas Yojana (PMAY)has announced providing housing to the urban poor. It may encourage migrant labourers to stay in urban areas and address the COVID-19 crises in the future. The housing purpose government starts the Affordable Rental Housing Complexes (ARHCs) in urban areas with the Public-Private Partnership. Even concession rental many government housing complexes lying vacant. The government also aims to incentivize industries, manufacturing units, and institutions to develop AHRC on their unutilized land. The government takes some appreciable steps, but no steps are taken to provide social security for migrant and informal sector workers.

\section{Conclusion}

Labour movement and the labour market flexibility are crucial for any country's economic trajectory. Internal migration being a predominant channel for the same. 


\section{International Journal of Social Science and Economic Research}

ISSN: $2455-8834$

Volume:06, Issue:07 "July 2021"

India has been no exception, and internal labour in India is urban-centric and causes growing regional disparity. The census 2011 migration data revealed that the majority of the migrants are possessed low-level education. Coupled with agriculture distress and low bargaining power, it has led to a disproportionate share of migrant labourers engaged in low-skilled and informal occupations at urban centers. Migrant labourers are not an entitlement for social protection, decent work. The enumeration is the policymaker's concern. Due to the pandemic, production activities are ceased and instigate a chaotic state of return migration, particularly net out migrant states. The DBT has been a positive initiative to reach the migrant labourers, but methodological issues have kept the circular migration outside the ambit of migrants. Self-declaration required by the states for direct benefit transfer has provided some relief in this regard. Most of the policies and programs are announced during the lockdown to address the effect of COVID-19 is already in operation. AtmaNirbhar Bharath and MGNREGs are the most welcome step for generating employment for migrants in India. The high inflation, hike in fuel prices, and low employment impact many sectors. The low level of GST collection and the center -state conflict for GST compensation indicate fiscal stress.

\section{Bibliography}

Abbas, R., \& Varma, D. (2014). Internal Labor Migration in India Raises Integration Challenges for Migrants, Migration Policy Institute.

Action Aid India (2020), Workers-in-the-time-of-Covid-19, Action Aid India, August.

Aiyaar Y. (2020).Don't wait for the perfect database. Modi govt can do cash April.

Bhagat, R. B., Reshmi, R. S., Sahoo, H., Roy, A. K., \&Govil, D. (2020). The COVID-19, Migration, and Livelihood in India (No. id: 13054).

Budget and Governance Accountability, May.

CBGA (2020), Numbers on Edge: India's Fiscal Response to Covid-19, Centre for

Chakraborty, L., \& Thomas, E. (2020). COVID-19 and Macroeconomic Uncertainty:

Chand R., Srivastava S.K and Singh J. (2017) Changing Structure of Rural Economy

Choudhury, S. R., \&Joarder, S. (2020). Reverse Migration Due to Long Lockdown in India-Is it Sustainable?. International Journal of Engineering and Management Research, 10(4).

Dandekar, A., \&Ghai, R. (2020). Reverse Migration in the Age of COVID-19, Economic and Political Weekly, Vol. 55, No. 19, page 28-31. 
International Journal of Social Science and Economic Research

ISSN: 2455-8834

Volume:06, Issue:07 "July 2021"

Fiscal and Monetary Policy Response, NIPFP Working Paper No. 20/302.

Guadagno, L. (2020). Migrants and the COVID-19 pandemic: An initial analysis. International Organization for Migration, Migration Research Series, (60).

India. Archives of Medical Research, June, (ARCMED_2020_848).

Institution for Transforming India, NITI Aayog, Delhi.

Maji, A., Sushma, M. B., \&Choudhari, T. (2020). The implication of the Inter-State Movement of Migrant Workers during COVID 19 Lockdown using Modified SEIR Model. arXiv preprint arXiv:2005.04424.

Mukhra, R., Krishan, K., \& Kanchan, T. (2020), Covid-19 Sets off Mass Migration in19 crisis through a migration lens (No. 147828, pp. 1-50). The World Bank,

Mundle S and S Sikdar (2020), Subsidies, Merit Goods and the Fiscal Space for transfers now, The Print, May 26th.

Nanda P. (2020), India's overall unemployment rate touches a nine-week high at of India Implications for Employment and Growth, Discussion Paper, National

Political Weekly, Vol. 55, No. 5, February 1st, page 52-60.

Ratha, D. K., De, S., Kim, E. J., Plaza, S., Seshan, G. K., \&Yameogo, N. D. (2020). COVID Reviving Growth: An Aspect of Public Expenditure in India, Economic \&

Sikdar, S., \& Mishra, P. (2020). Reverse Migration during Lockdown: A Snapshot of Public Policies (No. 20/318).

Srivastava, R. (2020). Understanding circular migration in India: Its nature and dimensions, the crisis under lockdown, and the state's response. Institute for Human Development, Centre for Employment Studies Working Paper Series-WP, 4, 2020.

UNICEF. (, 2020). Returning home: Effects of COVID-19 on migrant households in Bihar. 